\title{
Steroids from the Myxobacterium Nannocystis exedens
}

\author{
By WERNER KOHL, AXEL GLOE $†$ AND HANS REICHENBACH* \\ GBF, Gesellschaft für Biotechnologische Forschung, Mascheroder Weg 1, D-3300 Braunschweig, \\ Federal Republic of Germany
}

(Received 14 September 1982; revised 7 December 1982)

Squalene and three sterols were isolated from Nannocystis exedens (Myxobacterales). The sterol content was about $0.4 \%$ of the dry weight; squalene content was in the same range. The main component was identified as cholest-8(9)-en-3 $\beta$-ol. $\left[{ }^{14} \mathrm{C}\right] \mathrm{Mevalonate}$ was readily incorporated into the sterols. The bacterium was not inhibited by nystatin or amphotericin $B$.

\section{INTRODUCTION}

During an investigation into the carotenoids of Nannocystis exedens, a ubiquitous soil bacterium (Reichenbach, 1970), substantial amounts of steroid-like lipids were discovered. In addition, a substance with the retention time of squalene appeared in the gas-liquid chromatogram. As steroids are quite unusual in prokaryotes, we decided to isolate and characterize these compounds.

\section{METHODS}

Strains and culture conditions. Nannocystis exedens strain $\mathrm{Na}$ el( $=N$. exedens $\mathrm{HR} 1=$ German Collection of Microorganisms DSM 71 ; type strain: Reichenbach, 1970) was used for the chemical investigation. The organism was cultivated in 1 litre Erlenmeyer flasks containing $300 \mathrm{ml}$ PL liquid medium [consisting of Probion LS 600 (single cell protein; Hoechst), $1 \% ; \mathrm{MgSO}_{4} .7 \mathrm{H}_{2} \mathrm{O}, 0 \cdot 1 \%$ and $\mathrm{CaCl}_{2} .2 \mathrm{H}_{2} \mathrm{O}, 0 \cdot 1 \% ; \mathrm{pH} 7 \cdot 0$, autoclaved]. The flasks were shaken at $30^{\circ} \mathrm{C}$ at 160 r.p.m. From 8.71 of culture, $235 \mathrm{~g}$ of wet cells were obtained, corresponding to about $60 \mathrm{~g}$ dry wt. Alternatively the organism was grown in MDl medium [consisting of Casitone (Difco), $0 \cdot 3 \%$ : $\mathrm{CaCl}_{2} .2 \mathrm{H}_{2} \mathrm{O}, 0.05 \% ; \mathrm{MgSO}_{4} .7 \mathrm{H}_{2} \mathrm{O}, 0.2 \%$; cyanocobalamine, $0.5 \mathrm{mg} \mathrm{l}^{-1}$; and trace elements solution; $\mathrm{pH} 7.2$. autoclaved]. Cell yields were much lower in this medium. The incorporation experiments were performed with $N$. exedens strain Na el58 $(=N$. exedens HR 2), isolated in 1980 from field soil collected near Cairo, Egypt.

Isolation of steroids. The wet cell mass $(235 \mathrm{~g}$ ) was extracted three times with $250 \mathrm{ml}$ acetone, and the aqueous acetone solution was extracted three times with $200 \mathrm{ml}$ toluene. After removal of the toluene under vacuum, there remained $1.1 \mathrm{~g}$ of crude material. GLC of an aliquot, with cholesterol as a standard, showed that this material contained about $220 \mathrm{mg}$ of steroids. The crude material was dissolved in $\mathrm{CH}_{2} \mathrm{Cl}_{2} /$ methanol $(1: 1$, v/v) and chromatographed on a column $(850 \times 35 \mathrm{~mm})$ of Sephadex $\mathrm{LH}-20$ with $\mathrm{CH}_{2} \mathrm{Cl}_{2} /$ methanol as the eluant. There were 90 fractions of $15 \mathrm{ml}$ each, and steroids could be demonstrated by TLC in fractions 48 to 65 (total residue $300 \mathrm{mg}$ ). This material was chromatographed on a silica gel column (Lobar column size B, self-packed with LiChrosorb Si60 silica gel, $10 \mu \mathrm{m}$ particles; Merck) with hexane/acetone $(6: 4, \mathrm{v} / \mathrm{v})$ as the eluant. GLC of the 170 fractions ( $1 \mathrm{ml}$ each) showed the steroids to be in fractions 51 to 86 (total residue $210 \mathrm{mg}$ ).

Analytical chromatography. For TLC, silica gel on aluminium sheets (Merck) was used, with acetone/hexane $(35: 65, \mathrm{v} / \mathrm{v})$ as the solvent, the steroids having an $R_{f}$ of 0.6 . The acetylated steroids were chromatographed on silica gel (Kieselgel $60 \mathrm{HF}_{254}$; Merck) impregnated with $10 \%(\mathrm{w} / \mathrm{w}) \mathrm{AgNO}_{3}$ and activated by heating at $110^{\circ} \mathrm{C}$ for $30 \mathrm{~min}$; using toluene/ethyl acetate $(9: 1, \mathrm{v} / \mathrm{v})$, the $R_{f}$ values of the sterol acetates were $0 \cdot 44,0 \cdot 52$ and 0.58 . For detection the plates were sprayed with a solution of $2 \%(\mathrm{w} / \mathrm{w}) \mathrm{SbCl}_{5}$ in $\mathrm{CHCl}_{3}$ and heated to $110^{\circ} \mathrm{C}$.

GLC was performed on a Hewlett-Packard 5730 chromatograph equipped with a glass column $(2 \mathrm{~m} \times 4 \mathrm{~mm})$ containing $3 \%(\mathrm{w} / \mathrm{w})$ OV-17 on Chromosorb W HP, 80 to 100 mesh. The carrier gas was helium $\left(20 \mathrm{ml} \mathrm{min}^{-1}\right)$, the temperature was either programmed from 250 to $300{ }^{\circ} \mathrm{C}\left(8^{\circ} \mathrm{C} \mathrm{min} \mathrm{m}^{-1}\right)$ or held at $300{ }^{\circ} \mathrm{C}$, and detection was by

† Present address: Lehrstuhl für Mikrobiologie der Technischen Universität, Gaußstr. 7, D-3300 Braunschweig, F.R.G. 
thermal conductivity. Under isothermal conditions the retention time for squalene was $1.2 \mathrm{~min}$, and that for the sterols (one broad peak) $3.6 \mathrm{~min}$. Alternatively, a Siemens Sichromat 1 chromatograph was used, equipped either with a quartz capillary $(25 \mathrm{~m} \times 25 \mathrm{~mm})$ containing SP 2100 , or with a quartz capillary $(25 \mathrm{~m} \times 35 \mathrm{~mm})$ containing OV-1701. The carrier gas was again helium $\left(0.8 \mathrm{ml} \mathrm{min}{ }^{-1}\right)$ at a temperature of $280^{\circ} \mathrm{C}$. A flame ionization detector and a 1:80 inlet splitting ratio was used. Combined GLC-mass spectroscopy was done on a Perkin-Elmer F 22 chromatograph equipped with a quartz capillary $(15 \mathrm{~m} \times 0.25 \mathrm{~mm})$ containing DB $1-15 \mathrm{~N}$ (= SE 30, from Chrompack). The carrier gas was helium $\left(0.8 \mathrm{ml} \mathrm{min}{ }^{-1}\right)$ and the temperature was programmed from 150 to $300^{\circ} \mathrm{C}\left(6^{\circ} \mathrm{C} \mathrm{min-1)}\right.$. The chromatograph was connected via an open coupling to an AEI MS 30 mass spectrometer (ionization energy $24 \mathrm{eV}$; resolution $M / \Delta M=1000$, i.e. $10 \%$ valley; scanning interval $6 \mathrm{~s}$ ).

Acetylation of steroids. The steroid fraction $(200 \mathrm{mg})$ was dissolved in $5 \mathrm{ml}$ pyridine and treated with $5 \mathrm{ml}$ acetic anhydride for $12 \mathrm{~h}$ at room temperature. The dry residue was chromatographed on a silica gel column, as above, with hexane/diethyl ether $(8: 2, \mathrm{v} / \mathrm{v})$ as the eluant, yielding $180 \mathrm{mg}$ of acetates. By slow crystallization from methanol, $30 \mathrm{mg}$ of the main product was obtained from the mixture, with a melting point of $123-124^{\circ} \mathrm{C}$.

NMR spectroscopy. A Bruker WH 400 spectrometer was used to record un-decoupled ${ }^{13} \mathrm{C}$ spectra with $\mathrm{C}^{2} \mathrm{HCl}_{3}$ as the solvent and tetramethylsilane as the internal standard.

Labelling studies. Strain $\mathrm{Na}$ e 158 was grown in $150 \mathrm{ml} \mathrm{PL}$ medium in a $500 \mathrm{ml}$ conical flask at $30^{\circ} \mathrm{C}$ with shaking (160 r.p.m.). Immediately after inoculation (at $10 \%, v / v), 15 \mu \mathrm{Ci}$ of $N, N^{\prime}$-dibenzylethylenediamine-di-DL- 2 ${ }^{14} \mathrm{C}$ ]mevalonate [Amersham, specific activity $53 \mu \mathrm{Ci} \mathrm{mmol}{ }^{-1}\left(1.96 \mathrm{MBq} \mathrm{mmol}^{-1}\right)$ or $26.5 \mathrm{mCi} \mathrm{mmol}^{-1}$ $\left(980 \cdot 5 \mathrm{MBq} \mathrm{mmol}^{-1}\right)$ with respect to free mevalonic acid] was added. The dark red culture was harvested by centrifugation after $47 \mathrm{~h}$; the yield of wet mass $(5 \cdot 1 \mathrm{~g})$ was kept frozen at $-20^{\circ} \mathrm{C}$ until the steroids were extracted with acetone. At the beginning and at the end of the incubation period, samples $(0.2 \mathrm{ml})$ were taken and their radioactivity was determined in a Packard Tri-Carb liquid scintillation spectrometer. The total radioactivity (medium plus cells) was initially $2.4 \times 10^{7}$ c.p.m. and remained constant till the end. At harvest time, $0.5 \mathrm{ml}$ samples were pipetted into $5 \mathrm{ml}$ ice-cold $14 \%(\mathrm{w} / \mathrm{v})$ TCA. After standing for $45 \mathrm{~min}$ in an ice-bath, the precipitate was collected on glass microfibre filters (Whatman GF/B), washed once with $5 \mathrm{ml}$ cold $5 \%$ TCA and three times with $5 \mathrm{ml}$ water. Total radicactivity in TCA-insoluble material was $1.3 \times 10^{6}$ c.p.m., or about $5 \%$ of the added radioactivity. Incorporation of ${ }^{14} \mathrm{C}$ into the steroids was determined by HPLC on a prepacked Hibar EC column $(125 \times 4 \mathrm{~mm}$ ) of LiChrosorb RP-18, $5 \mu \mathrm{m}$ particles (Merck) with the solvent system methanol/diethyl ether/water (78.5:17:4-5, by vol.). The chromatograph (Waters) was equipped with a UV-detector ( $210 \mathrm{~nm}$; Kontron Uvikon 725 ) and a ${ }^{14} \mathrm{C}$-detector (Packard Tri-Carb RAM) with a $100 \mu$ l flow-through cell.

Inhibition studies. Strain $\mathrm{Na}$ e 158 was grown in $50 \mathrm{ml}$ of either PL or MDl medium in shake cultures at $30^{\circ} \mathrm{C}$. Immediately after inoculation, varying amounts of nystatin (Mycostatin; Serva) or amphotericin B (Calbiochem), both dissolved in methanol $(10 \mathrm{mg}$ in $20 \mathrm{ml})$, were added.

\section{RESULTS}

Cells of the myxobacterium $N$. exedens strain $\mathrm{Na}$ el were extracted with acetone. The crude extract was purified by Sephadex LH-20 and silica-gel chromatography, and the resulting material analysed by GLC. The gas chromatogram showed a strong peak with the same retention time as authentic squalene, from which our compound did not separate upon cochromatography. In addition, there was a major and a minor peak in the region of cholesterol; however, both peaks differed slightly from cholesterol in their retention times. Combined GLCmass spectroscopy gave one molecular ion at $\mathrm{m} / \mathrm{z} 386$ for the major peak, and two molecular ions at $\mathrm{m} / \mathrm{z} 386$ and $\mathrm{m} / \mathrm{z} 384$ for the minor peak, the latter obviously containing two components which were not separated by GLC. The mass spectrum of the main component was very similar to that of cholesterol (Wulfson et al., 1964). There were, however, differences in the relative intensities of several peaks. The fragmentation pattern was too uncharacteristic to allow a deduction of the chemical structure; still, it seemed likely that the myxobacterial compounds differed from cholesterol merely in the position and, in case of $m / z 384$, in the number of double bonds. The squalene peak had its molecular ion at $m / z 410$ as expected.

As we did not succeed in separating the three sterols on thin layers of silica gel impregnated with $\mathrm{AgNO}_{3}$ (Ikan \& Cudzinovski, 1965), the mixture was acetylated. With the acetates we obtained three spots on silica gel/ $\mathrm{AgNO}_{3}$ (Copius-Peereboom \& Beeks, 1965), but they were too close together to allow easy separation on a preparative scale. On GLC the acetates appeared as three separate peaks in the quantitative ratio of $72: 18: 10$ (Fig. 1). The acetylated main component was purified by crystallization from methanol. The ${ }^{13} \mathrm{C}-\mathrm{NMR}$ of the acetate of the main compound had signals at $\delta 11 \cdot 3(\mathrm{q}), 17 \cdot 7(\mathrm{q}), 18 \cdot 8(\mathrm{q}), 21 \cdot 4(\mathrm{q}), 22 \cdot 6(\mathrm{q}), 22 \cdot 8(\mathrm{q}), 23.8(\mathrm{t})$, 


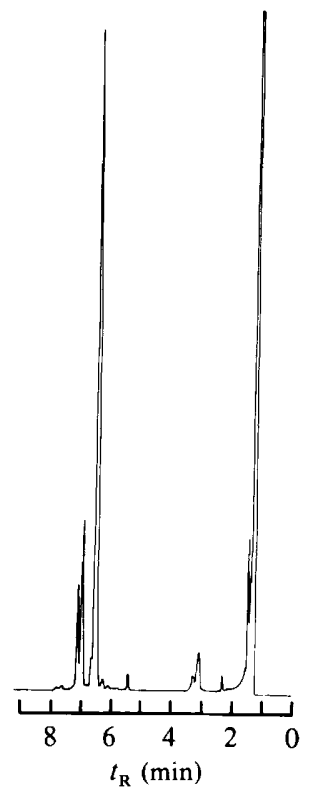

Fig. 1. Capillary GLC of the acetylated sterol fraction of $N$. exedens. The peaks of the three sterol acetates are between $t_{\mathrm{R}} 6.5$ and 7.5 . A sichromat with a quartz capillary $(25 \mathrm{~m} \times 0.35 \mathrm{~mm})$ containing OV-1701 was used.<smiles>CC(C)CCCC(C)C1CCC2C3=C(CC[C@]21C)[C@@]1(C)CCC(O)CC1CC3</smiles>

Fig. 2. Cholest-8(9)-en-3 $\beta$-ol, the main sterol of $N$. exedens.

$24 \cdot 0(\mathrm{t}), 25 \cdot 4(\mathrm{t}), 27 \cdot 1(\mathrm{t}), 27 \cdot 7(\mathrm{t}), 28 \cdot 0(\mathrm{~d}), 28 \cdot 8(\mathrm{t}), 34 \cdot 3(\mathrm{t}), 35 \cdot 0(\mathrm{t}), 35 \cdot 7(\mathrm{~s}), 36 \cdot 2(\mathrm{t}), 36 \cdot 3(\mathrm{~d}), 37 \cdot 0$ $(\mathrm{t}), 39.6(\mathrm{t}), 40.7(\mathrm{~d}), 42 \cdot 2(\mathrm{~s}), 51.9(\mathrm{~d}), 55 \cdot 0(\mathrm{~d}), 73.6(\mathrm{~d}), 128 \cdot 4(\mathrm{~s}), 134.8(\mathrm{~s}), 170.5(\mathrm{~s})(\mathrm{q}=$ quartet, $\mathrm{t}=$ triplet, $\mathrm{d}=$ doublet, and $\mathrm{s}=$ singlet). This spectrum was identical with that of the acetate of cholest-8(9)-en-3 $\beta$-ol (Tsuda \& Schroepfer, 1979; Fig. 2). The melting point of our acetate $\left(123\right.$ to $\left.124{ }^{\circ} \mathrm{C}\right)$ was identical with published data $\left(123.5\right.$ to $125^{\circ} \mathrm{C}$; Hylands et al., 1977). The structure was also confirmed by X-ray analysis (Dr William S. Sheldrick, GBF, personal communication). The minor components were present in the mother liquor in too small quantities to allow an unequivocal structure elucidation. The quantities of steroid isolated from $N$. exedens were quite substantial, being about $0.4 \%$ of the total dry weight. The squalene content was in approximately the same range, but was found to vary considerably from experiment to experiment.

As steroids are ubiquitous in eukaryotes and may easily be introduced as impurities of medium components or in solvents, unequivocal proof for de novo synthesis of the isolated compounds by $N$. exedens was indispensable. Strain $\mathrm{Na}$ el was cultivated in two different media. Large-scale preparations were cultivated in PL medium because it permitted superior growth. The main component of this medium, Probion, is a single cell protein preparation produced by Hoechst from methanol-utilizing Methylomonas clara (Schlingmann et al., 1982). Analysis of Probion LS 600 showed no tiace of squalene or steroids; nor are steroids mentioned in the published lipid analyses of M. clara (Schlingmann et al., 1982; Tiemeyer \& Rambeck, 


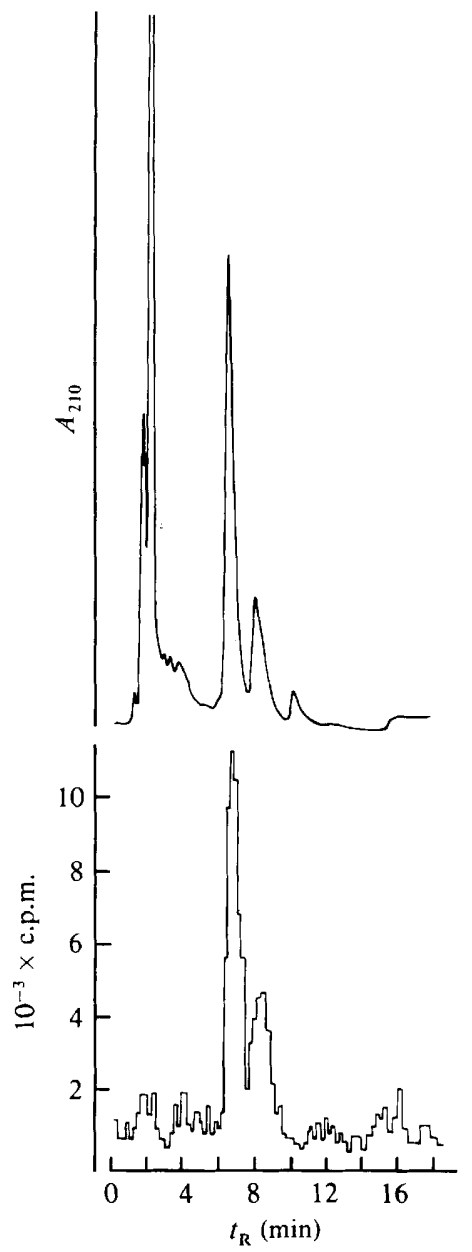

Fig. 3. HPLC of the sterol fraction of $N$. exedens grown in presence of $\left[{ }^{1+} \mathrm{C}\right]$ mevalonate. Upper trace: detection by UV absorbance with two sterol peaks at $t_{\mathrm{R}} 7$ and 8 . Lower trace: distribution of radioactivity along the same profile.

1982). Alternatively, Na el was cultivated in MD1 medium, based on steroid-free Casitone (Difco), giving a quantitatively different pattern of the same three steroids. When large quantities of acetone (Merck) were evaporated, the residue contained no steroids. To demonstrate de novo synthesis by use of tracer studies $\left[{ }^{14} \mathrm{C}\right]$ mevalonate, the precursor of the carbon skeleton of squalene and the steroids, was added to cultures of strain $\mathrm{Na}$ e158, which has the same steroid pattern as $\mathrm{Na}$ el. The radioactivity was incorporated efficiently into TCAinsoluble material (about $5 \%$ of the added radioactivity), and the three sterols became heavily and specifically labelled, as shown by analysis of the extract by HPLC combined with ${ }^{14} \mathrm{C}$ detection (Fig. 3). The two sterol peaks contained more than $80 \%$ of the radioactivity of the sample.

The antifungal polyene antibiotics act by binding to membrane steroids (for a review, see Hamilton-Miller, 1974). To determine whether $N$. exedens was sensitive to these inhibitors, strain $\mathrm{Na}$ e158 was grown in two different media in the presence of either nystatin or amphotericin B at 5,15 and $30 \mu \mathrm{g} \mathrm{ml}^{-1}$. Only with amphotericin B at the exceedingly high concentration of $30 \mu \mathrm{g} \mathrm{ml}^{-1}$ was a slightly reduced pigmentation and a delay in culture development occasionally observed. When inocula of $N$. exedens on agar plates were dusted with nystatin or amphotericin B powder, the bacteria invariably grew out from between the 
antibiotic particles, while growth of moulds under the same circumstances was completely inhibited. In fact we have used this method routinely to purify newly isolated Nannocystis strains from contaminating fungi.

\section{DISCUSSION}

Almost all eukaryotic cells contain steroids as constituents of their membranes, usually in the range of 25 to $30 \%$ of the total lipid (Razin, 1978). Filamentous fungi may contain between $0 \cdot 1$ and $4 \%$ of their dry matter as steroids, and yeasts occasionally have up to $10 \%$ (Weete, 1980). In contrast, steroids have been found in relatively few prokaryotes and then usually in very small quantities. Many mycoplasmas (genera Mycoplasma and Spiroplasma) grow only in presence of steroids, which they incorporate into their membranes (Smith \& Lynn, 1958; Smith \& Rothblat, 1962; Razin, 1978) and the same seems to be the case with several serum-dependent treponemas (Lemcke \& Burrows, 1980). Steroids seem to be widely distributed among cyanobacteria, e.g. Anacystis nidulans and Fremyella diplosiphon (small quantities; Reitz \& Hamilton, 1968), Phormidium luridum $(0.01$ to $0.02 \%$ of the dry weight; de Souza \& Nes, 1968), Spirulina maxima (no quantities given; Martinez Nadal, 1971), and Spirulina platensis, Calothrix sp. and Nostoc commune (no quantities given; Paoletti et al., 1976). Steroids have also been isolated from the new phototrophic prokaryote, Prochloron (no quantities given; Perry et al., 1978). Steroids in trace amounts were detected in extracts from Escherichia coli $(0 \cdot 0004 \%$; Schubert et al., 1964) [a result not corroborated by other laboratories (Nes et al., 1980)], in Streptomyces olivaceus $(0.0035 \%$; Schubert et al., 1967) and in Methylobacterium organophilum $(0.00003 \%$; Patt \& Hanson, 1978). Small to moderate quantities of steroids were found in Azotobacter chroococcum $(0.01 \%$; Schubert et al., 1968), Cellulomonas dehydrogenans $(0.03$ to $0.05 \%$; Weeks \& Francesconi, 1978), and stable L-forms of Staphylococcus aureus (0.03 to $0.05 \%$; Hayami et al., 1979). A sterol has been found in Corynebacterium simplex grown on n-alkanes, but no data on structure or quantity are given (Yanagawa et al., 1972). There is only one other bacterium that produces quantities of steroids comparable to those of $N$. exedens $(0.4 \%)$, viz. Methylococcus capsulatus grown on methane $(0 \cdot 22 \%$; Bird et al., 1971).

The occurrence of squalene in prokaryotes is more common. The many bacteria that synthesize hopanoids (Rohmer et al., 1979) must also contain squalene, the direct precursor for these triterpenes. Traces of squalene are reported from Phormidium luridum (de Souza \& Nes, 1968), Prochloron (Perry et al., 1978), Rhodospirillum rubrum and Rhodomicrobium vannielii (Han \& Calvin, 1969; Bird et al., 1971), and Cellulomonas dehydrogenans $(0.002$ to $0.005 \%$; Weeks \& Francesconi, 1978). More substantial quantities have been isolated from Staphylococcus aureus $(0.01 \%$, in addition to $0.08 \%$ dehydrosqualene; Suzue et al., 1968), Methylobacterium organophilum $(0.07 \%$; Patt \& Hanson, 1978), Halobacterium cutirubrum $(0.15 \%$ including di- and tetrahydrosqualenes; Tornabene et al., 1969; Kramer et al., 1972), and Methylococcus capsulatus $(0.55 \%$; Bird et al., 1971). Nannocystis exedens falls into the upper range $(0.1$ to $0.3 \%)$.

The determination of the structure of bacterial steroids has not always been unequivocal because of the small amounts available. In almost all cases more than one steroid was present, and without exception they were $3 \beta$-sterols. The cyanobacteria and Prochloron contained cholesterol and C24-methylated and C24-ethylated sterols and homologues with variations of double bond number and position. From Methylococcus capsulatus, 4-methyl and 4,4-dimethyl cholestenols with various combinations of double bonds in the $8(9)$ and 24 positions were isolated. Methylobacterium organophilum contained 4,4,14-trimethyl-cholesta-8(9),22,24-trienol, Cellulomonas dehydrogenans contained cholesterol and $\beta$-sitosterol, Staphylococcus L-forms and Streptomyces olivaceus contained cholesterol, and Azotobacter chroococcum contained several ergestenols and C4-methylated sterols. Nannocystis exedens with its cholest-8(9)-en-3 $\beta$-ol fits well into this picture. Obviously, prokaryotes do not conform to the distinction between zoo-, phyto- and mycosterols (Weete, 1980).

De novo synthesis of squalene and steroids by prokaryotes has been demonstrated in several cases, usually by incorporation studies. Suzue et al. (1968), working with a Staphylococcus in vitro system, obtained $\left[{ }^{14} \mathrm{C}\right]$ squalene from $\left[{ }^{14} \mathrm{C}\right]$ farnesyl pyrophosphate. Cellulomonas dehydrogenans 
incorporated radioactivity from $\left[{ }^{14} \mathrm{C}\right]$ glucose into squalene and sterols (Weeks \& Francesconi, 1978), stable L-forms of Staphylococcus aureus incorporated $\left[{ }^{14} \mathrm{C}\right]$ acetate into cholesterol (Hayami et al., 1979), and Halobacterium cutirubrum incorporated $\left[{ }^{14} \mathrm{C}\right]$ acetate into squalene (Tornabene et al., 1969). Squalene cyclase was isolated from Methylococcus capsulatus and studied in vitro (Rohmer et al., 1979). On the other hand, Reitz \& Hamilton (1968) could not achieve the incorporation of $\left[{ }^{14} \mathrm{C}\right]$ acetate into steroids by cyanobacteria, although $\mathrm{CO}_{2}$, phytol and fatty acids became labelled. In our case, the sterols became intensively labelled when $\left[{ }^{14} \mathrm{C}\right]$ mevalonate was added to the culture, leaving no doubt about their origin.

The bacterial steroids, like those of eukaryotes, are probably located in the cellular membranes, although direct experimental evidence is lacking in most cases. Cholesteroldependent and cholesterol-independent mycoplasmas incorporate exogenous cholesterol exclusively into their membranes (Smith \& Rothblat, 1962; Bittman \& Rottem, 1976; Razin, 1978). Gram-positive and Gram-negative bacteria may possibly behave like Acholeplasma and incorporate exogenous cholesterol into their membranes (the Gram-negative organisms preferentially into their cytoplasmic membranes) (Smith \& Rothblat, 1962; Razin, 1975). Polyene antibiotics, like nystatin, amphotericin and filipin, act by binding to membrane sterols, and thus are usually non-toxic for prokaryotes. However, Mycoplasma is inhibited, and Acholeplasma becomes sensitive when grown in presence of cholesterol (for review, see Hamilton-Miller, 1974). Interestingly, $N$. exedens is totally resistant to nystatin and amphotericin B. Also several cyanobacteria were completely resistant to amphotericin A, and only Phormidium responded to high concentrations of nystatin (Hunter \& McVeigh, 1961). These observations apparently do not support the idea of sterols as essential membrane components in these bacteria; however, it is possible that the antibiotics are simply kept from the cytoplasmic membrane by the barrier of the (sterol-free?) outer membrane.

Steroids seem to be present in most, perhaps all, Nannocystis strains. It remains to be seen whether different steroids are synthesized by different strains, and whether there are steroid producers among other myxobacteria and gliding bacteria.

Probion was a gift from the Hoechst company. Dr D. Claus, DSM, provided the soil sample from which strain $\mathrm{Na}$ e158 was isolated. The GLC-mass spectra and ${ }^{13} \mathrm{C}-\mathrm{NMR}$ spectra were recorded by the Spectroscopy Department of the GBF. Miss Susanne Petersen, Miss Bettina Evert and Miss Barbara Witte provided careful technical assistance. We wish to thank all these persons for their cooperation.

\section{REFERENCES}

Bird, C. W., LYNCH, J. M., PIRT, F. J., REID, W. W., Brooks, C. J. W. \& Middleditch, B. S. (1971).

Steroids and squalene in Methylococcus capsulatus grown on methane. Nature, London 230, 473474.

Bittman, R. \& RotTem, S. (1976). Distribution of cholesterol between the outer and inner halves of the lipid bilayer of Mycoplasma cell membranes. Biochemical and Biophysical Research Communications 71, 318-324.

Copius-Peereboom, J. W. \& Beeks, W. (1965). The analysis of mixtures of animal and vegetable fats. V. Separation of sterol acetates by thin-layer chromatography in reversed-phase systems and on silica gel-G silver nitrate layers. Journal of Chromatography 17, 99-113.

Hamilton-Miller, J. M. T. (1974). Fungal sterols and the mode of action of the polyene antibiotics. Adrances in Applied Microbiology 17, 109-134.

HaN, J. \& Calvin, M. (1969). Hydrocarbon distribution of algae and bacteria, and microbiological activity in sediments. Proceedings of the National Academy of Sciences of the United States of America 64, 436-443.
Hayami, M., Okabe, A., Sasai, K., Hayashi, H. \& Kanemasa, Y. (1979). Presence and synthesis of cholesterol in stable staphylococcal L-forms. Journal of Bacteriology 140, 859-863.

HunTer, E. O. \& MCVEIGH, I. (1961). The effects of selected antibiotics on pure cultures of algae. American Journal of Botany 48, 179-185.

Hylands, P. J., Midgley, J. M., Smith, C., Wallis, A. F. A. \& Whalley, W. B. (1977). Unsaturated steroids. Part 5. Synthesis of $4 \alpha$-methyl-cholest-8(9)en-3 $\beta$-ol. Journal of the Chemical Society. Perkin Transactions I, 817-819.

IKAN, R. \& CUDZINovski, M. (1965). Separation of sterols and corresponding stanols on thin layers of silica impregnated with silver nitrate. Journal of Chromatography 18, 422-423.

Kramer, J. K. G., Kushwaha, S. C. \& Kates, M. (1972). Structure determination of the squalene, dihydrosqualene and tetrahydrosqualene in Halobacterium cutirubrum. Biochimica et biophysica acta 270, 103-110.

Lemcke, R. M. \& Burrows, M. R. (1980). Sterol requirement for the growth of Treponema hyodysenteriae. Journal of General Microbiology 116, 539-543. 
Martinez Nadal, N. G. (1971). Sterols of Spirulina maxima. Phytochemistry 10, 2537-2538.

Nes, W. R., Adler, J. H., Frasinel, C., Nes, W. D., Young, M. \& JosePH, J. M. (1980). The independence of photosynthesis and aerobiosis from sterol biosynthesis in bacteria. Phytochemistry 19, 1439 1443.

Paoletti, C., Pushparaj, B., Florenzano, G., CaPELlA, P. \& LERCKER, G. (1976). Unsaponifiable matter of green and blue-green algal lipids as a factor of biochemical differentiation of their biomasses. II. Terpenic alkohol and sterol fractions. Lipids 11, 266271

PatT, T. E. \& Hanson, R. S. (1978). Intracytoplasmic membrane, phospholipid, and sterol content of Methylobacterium organophilum cells grown under different conditions. Journal of Bacteriology 134, 636-644.

Perry, G. J., Gillan, F. T. \& Johns, R. B. (1978). Lipid composition of a prochlorophyte. Journal of Phycology 14, 369-371.

RAZIN, S. (1975). Cholesterol incorporation into bacterial membranes. Journal of Bacteriology 124, 570 572 .

RAZIN, S. (1978). The mycoplasmas. Microbiological Reviews 42, 414-470.

ReichenbaCH, H. (1970). Nannocystis exedens gen. nov., spec. nov., a new myxobacterium of the family Sorangiaceae. Archir für Mikrobiologie 70, 119-138.

ReITZ, R. C. \& Hamilton, J. G. (1968). The isolation and identification of two sterols from two species of blue-green algae. Comparative Biochemistry and Physiology 25, 401-416.

Rohmer, M., Bouvier, P. \& Ourisson, G. (1979). Molecular evolution of biomembranes: structural equivalents and phylogenetic precursors of sterols. Proceedings of the National Academy of Sciences of the United States of America 76, 847-851.

SchlingmanN, M., Faust, U. \& Präve, P. (1982). Aufarbeitung und Isolierung funktioneller Bioproteine. In Mikrobielle Proteingewinnung und Biotechnologie, pp. 117-124. Edited by P. Präve, K. Schügerl \& H. Zucker. Weinheim: Verlag Chemie SChubert, K., Rose, G., Tummler, R. \& IKeKaWa, N. (1964). Sterine in Escherichia coli. Hoppe Seyler's Zeitschrift für physiologische Chemie 339, 293-296.

SCHUbert, K., RoSE, G. \& HöRhold, C. (1967). Cholesterin in Streptomyces olitaceus. Biochimica et biophysica acta 137, 168-171.
Schubert, K., Rose, G., Wachtel, H., Hörhold, C. \& IKEKAWA, N. (1968). Zum Vorkommen von Sterinen in Bakterien. European Journal of Biochemistry 5, 246-251.

SMith, P. F. \& LYNN, R. J. (1958). Lipid requirements for the growth of pleuropneumonia-like organisms. Journal of Bacteriology 76, 264-269.

Smith, P. F. \& Rothblat, G. H. (1962). Comparison of lipid composition of pleuropneumonia-like and Ltype organisms. Journal of Bacteriology 83, 500-506.

DE SOUZA, N. J. \& NES, W. R. (1968). Sterols: isolation from a blue-green alga. Science 162, 363 .

Suzue, G., Tsukada, K., Nakai, C. \& Tanaka, S. (1968). Presence of squalene in Staphylococcus. Archices of Biochemistry and Biophysics 123, 644.

TIEMEYER, W, \& Rambeck, W. (1982). Analytische Charakterisierung von nicht-proteinartigen Begleitstoffen in einem SCP (Methylomonas clara). In Mikrobielle Proteingewinnung und Biotechnologie, pp. 183-188. Edited by P. Präve, K. Schügerl \& H. Zucker. Weinheim: Verlag Chemie.

Tornabene, T. G., Kates, M., Gelpi, E. \& Oro, J. (1969). Occurrence of squalene, di- and tetrahydrosqualenes, and vitamin $\mathbf{M K}_{8}$ in an extremely halophilic bacterium, Halobacterium cutirubrum. Journal of Lipid Research 10, 294-303.

Tsuda, M. \& Schroepfer, G. J. (1979). Carbon-13 nuclear magnetic resonance studies of $\mathrm{C}_{27}$ sterol precursors of cholesterol. Journal of Organic Chemistry 44, 1290-1293.

WEEKs, O. B. \& FRANCESCONI, M. D. (1978). Occurrence of squalene and sterols in Cellulomonas dehydrogenans (Arnaudi 1942) comb. nov. Hester 1971. Journal of Bacteriology 136, 614-624.

WEETE, J. D. (1980). Lipid Biochemistry of Fungi and Other Organisms. New York: Plenum Press.

Wulfson, N. S., Zaretskil, V. J., Zaikin, V. G., Segal, G. M., Torgov, I. V. \& Fradkina, T. P. (1964). Mass spectrometric location of the double bond in steroid systems. Tetrahedron Letters, 3015 3022.

Yanagawa, S., Fuji, K., Tanaka, A. \& Fukui, S. (1972). Lipid composition and localization of 10methyl branched-chain fatty acids in Corynebacterium simplex grown on n-alkanes. Agricultural and Biological Chemistry 36, 2123-2128. 